\title{
The role of superior judiciary in protecting its independence: A case study of judicial legitimization of military regimes in Pakistan
}

\author{
Niaz Badshah* \\ Department of Political Science, University of Peshawar, Peshawar, Pakistan. \\ *Corresponding Author Email: niazbadshah.adv@gmail.com
}

\begin{abstract}
Pakistan has faced four military coups, three out of it were not declared illegitimate by supreme judiciary for the removal of civilian governments. On the contrary, the doctrine of necessity became the quoted terms as causes of accepting those extra-constitutional moves. While adjudicating these cases, military establishment either used their institutional influence or manured the judiciary to take afresh oath of allegiance of military rulers under provisional or interim constitutional orders. Thus, the cases before these judges were just hoodwinking or a lip service of endorsing and affixing a stamp of validity. Moreover, superior judiciary had authorized military rulers to amend the constitutions, which is sole prerogative of parliament as per constitutions of the time. Thus, superior judiciary was unable to stand in front of power dynamics, except in the case of Asma Gillani vs Federation of Pakistan, but its decision was adjudicated, when General Yahya Khan was not in power. While applying heterogeneous sampling technique, the study has attempted to accumulate a variety of expert opinions on the role and independence of judiciary vis-a-vis the military regimes. The findings show that decisions of superior courts, to assure smooth running of the country, sacrificed the spirit of the constitutions. Apex court's decisions only tried to maintain the status quo and to pave the way to let the new system run.
\end{abstract}

Keywords: Kelsen's Theory, doctrine of necessity, judicial judgments, military regimes, martial law, extra-constitutional moves, independence of judiciary.

How to Cite: Badshah, N. (2021). The role of superior judiciary in protecting its independence: A case study of judicial legitimization of military regimes in Pakistan. Journal of Humanities, Social and Management Sciences (JHSMS), 2(2), 65-76. https://doi.org/10.47264/idea.jhsms/2.2.6

Publisher's Note: IDEA PUBLISHERS (IDEA Journals Group) stands neutral regarding jurisdictional claims in the published maps and institutional affiliations.

Copyright: () 2021 The Author(s), published by IDEA PUBLISHERS (IDEA Journals Group).

Licensing: This is an Open Access article published under the Creative Commons AttributionNonCommercial 4.0 International License (http://creativecommons.org/licenses/by-nc/4.0/) 
The role of superior judiciary in protecting its independence: A case study of judicial ...

\section{Introduction}

Pakistan's judicial system had been inherited from the common law of the UK. And under the Government of India Act 1935 the independence of the judiciary was preserved to a great extent. As it plays a vital role in all spheres of a state. If a state's judiciary is independent, having separation of powers, people of the state will have confidence and expectations of fair trials, which is the core objective of a socially organized modern state. If the state courts are open and perfectly exercise their jurisdiction without any bar, Martial law could not be existed in that state (Dicey, 1885 [1959]). In fact, Pakistan was ruled by the Government of Indian Act 1935 as it was adopted till the enactment of the 1956 constitution. The institutions were functioning according to the sweet will as the head of the state institutions and they were fully involved in every sphere of the state affairs, with their ulterior motives, for instance, the governor general dismissed the prime minister several times in spite of the fact that they had complete confidence of the constituent assembly. There were signs of threat from military action and then a drastic action of dissolution of the constituent assembly was finally taken in 1954 (Mahmood, 1990).

The first constituent assembly of a newly born state of Pakistan on $15^{\text {th }}$ August 1947 was assigned a crucial job of devising a political system and constitution to be acceptable to both wings of Pakistan. It took nearly a decade to compile a compatible constitution but lastly the constituent assembly was dissolved. The bone of contention between both wings was on the role and power of center, provincial autonomy, religion in the state of Pakistan. In fact, Pakistan was assumed as a constitutional laboratory till 1973, during this period it has practiced various constitutions, namely of 1956, 1962 and in-term constitution of 1972 and finally the constitution of 1973 which was unanimously passed by the parliament. During this period Pakistan saw four armed coups, in which only one of General Muhammad Yahya Khan was declared as illegal, unconstitutional and ultra vires (when he was not in power). The rest of Armed coup d'état were legitimized by the Supreme Court of Pakistan time and again on various grounds i.e., Grundnorm of Kelsen's Pure Theory of Law, doctrine of state necessity, accountability and Islamization etc. in various cases the Supreme Court played an aligned role while deciding these important petitions.

\subsection{Statement of problem}

Pakistan has smoothly been running by the democratic institutions from the very beginning of the $21^{\text {st }}$ century but it is generally assumed that civil and military establishment has still control on the country politics and administration. There has been a heritage of the legacy of military rule in Pakistan which has affected the growth of independence of democratic institutions including the judiciary. This paper talks about how the apex judiciary legitimized the armed coup in the country. And how invalid judgments overshadowed the role of independent judiciary? It also focuses on how through political vision, different organs of the state of Pakistan were strengthened in relation with the rule of law.

\subsection{Scope of the research}

This research may lead to the findings that to what extent the independence of the judiciary in Pakistan were ensured by the superior judiciary itself while working under military regimes. This study highlights the circumstances and factors of that time through expert opinion. 


\subsection{Research questions}

- Whether Pakistan Supreme Judiciary ensured Judicial Independence while deciding Armed Coup's petitions or otherwise during 1947 to 2000 ?

- How and why the outcomes of the constitutional cases like Maulvi Tamizuddin case, Dosso case Yusaf Patel case, Asma Jilani case, Begum Nusrat Bhutto case and Syed Zafar Ali Shah etc. affected Pakistani Politics?

\subsection{Aims and objectives}

- To find out the various impacts of judgments of constitutional cases

- To discuss the role of judiciary behind the establishment of a series of Martial laws regimes in Pakistan

- To sort out the legitimate and illegitimate court decisions on selected constitutional cases on the bases of law, morality and tradition

- To determine that to what extent these judgments have affected the democratic culture in Pakistan

- To discuss the role of politicians/political parties who could not maintain a smooth democratic practice, to avoid the illegitimate undemocratic rule in the country

- To highlight and discuss the relativity of 'Law of Necessity' and 'Kelsen's Theory of Law to the Pakistan's jurisprudence.

\subsection{Justification/significance of the study}

This research will be beneficial for the researchers and students of Law, Politics and Pakistan Studies. As some of these verdicts have remained unpopular due to pending the democratic practices against the dictatorial rule in the country, an in-depth study will highlight the repercussions of such decisions. This study is going to create awareness that why the consistency of democratic rule is important for the development and growth of a country and why independence of judiciary is so important to avoid such repetitions, in a state jurisprudence. Every nation becomes successful when it learns from its mistakes. The judiciary alone cannot be blamed for the inconsistency of democratic rule in Pakistan but there may be some other factors that are also responsible for the prolonged dictatorial regimes in Pakistan. This study will lead to enhance the belief in democratic system in Pakistan.

\section{Literature review}

There are certain questions to be answered by the judicial experts on the verdicts given by the Supreme Court of Pakistan in certain famous cases concerning the validity of the martial rules in Pakistan. The survey was conducted based on heterogeneous sampling methods by selecting the people of researcher's choice on the subject although having different opinion bases. Democracy in a state of Pakistanis a very new imported brand of government. Due to security reasons, Pakistan remained to be garrison state (Ishtiaq, 2013). To strengthen military of Pakistan has always been a prerequisite for its security against Indian aggression as well as to meet the international challenges posed by the westernized allies to face the Russian aggression in Afghanistan and later to serve as a frontline state in the 'war on terror'. This needed role made international recognition for the dictatorial rule in Pakistan. The courts were well aware of the powers and importance of military rule in the country. They had no choice but mostly to 
The role of superior judiciary in protecting its independence: A case study of judicial ...

validate the military dictatorships under the doctrine of state necessity or other pretexts, but the causes for each armed coup d'état were almost identical time to time and again. The conducted survey has based on certain questions to be replied to in the light of judicial verdicts on the famous cases where the validity of the military rule was challenged and the political affairs of that time in the country and honorable judiciary decided these cases judiciously or otherwise?

Much has been written in this respect but actually the role of the supreme judiciary to ensure its independence in such like cases decision not specifically considered or elaborated in any of the existing literature. In the constitutional history of Pakistan by (Chaudhary, 1959) has discussed the dissolution of the first constituent assembly till the fall of Dacca (East Pakistan). No specific detail has been given to the proposed aspect of the study. In this connection (Khan, 2005) has also mentioned and surveyed the constitutional history in a composite manner in his book but there are rooms for improvements. Similarly, foreign writers such as (Newberg, 2002) have also discussed the issue in different manners, other than the proposed study in the "Judging the state". McGrath (1996) has also discussed in detail its pros and cons of political and democratic situation of the first decade. Last but not the least Zafar (2019) a constitutional lawyer of Pakistan, has also discussed the issue at a glance in his articles to some extend in elaborate manners. There is grey area in the existing literature which needs to be addressed in the present study (Zafar, 2019). In fact, it was test of the judicial independence and how the superior judiciary proved itself to be an independent impartial judiciary and has the courage to defuse the dynamics of power according to the state law or otherwise.

\section{Research methodology}

The study of the judgments from relevant volumes of PLD journal, available material on websites, books and journal articles are the selected sources of study for this research. There are also online lectures of the expert lawyers, politicians and Judges are to be consulted to have an in-depth study. Some interviews of various scholars and political experts on the subject will make the study interesting and thought provoking. This research study is based in socio-legal method, which deals with how society experiences and engages with law. There are several research techniques used in socio-legal research method, which include grounded theory, narratology, storytelling, and ethnography. For the present research the researcher employs narratology or narrative analysis that suits the subject matter of the study.

Two sociologists, Barney Glaser and Anselm Strauss, developed the grounded theory as a methodology in social sciences. It is called grounded theory because it is grounded in data. It helps the researcher to move from data to theory by progressive identification and integration of categories of meaning. This method is useful when there does not exist theories or limited number of theories and they do not satisfy researcher about the given issue. Grounded theory creates the possibility of developing contextualized theories. In the present research the researcher employs grounded theory method. Because there are no theories or theoretical models available on the problem - why the Supreme Court invoked the doctrine of necessity and Kelsen's Grundnorm each time in the wake of coups d'état in Pakistan? The researcher would employ the grounded theory to develop a theoretical model.

\section{Discussion and findings}

Due to General Muhammad Ayub Khan martial law the constitution of 1956 was abandoned 
in 1958. In 1962 another constitution was introduced by the military ruler General Muhammad Ayub Khan which was also abrogated by General Yahya Khan the then Chief of Army Staff of Pakistan by the invitation of general Muhammad Ayub Khan. The prevailing $3^{\text {rd }}$ constitution of Pakistan was introduced in 1973 which also could not maintain a smooth journey and has to be suspended, held in abeyance by the two martial law rulers i.e., Gen. Zia rule since 1977 to 1987 and another General Musharraf rule (2001-2008). During all these incidents, the legitimacy of the armed coups was questioned through various constitutional petitions. The aims were to restore the democracy in country in the long run, but unfortunately military rulers were granted a stamp of legitimacy, through judiciary in their verdicts on these constitutional petitions and the jurisdiction of the superior judiciary was minimized by the proclamation of provisional constitutional orders of the chiefs of martial law administrators.

The verdicts of the superior judiciary on the constitutional petitions were in favor of the military ruler and were also declared legitimized except in the case of Asma Jilani's Case that General Yahya Khan was declared as usurper when he was not in power. The role of judiciary is not appreciable in such like cases in the entire cases in the history of Pakistan. The Judiciary has provided legitimacy to the military rulers on the basis of various grounds i.e., 'the doctrine of state necessity' and 'the Kelsen's pure theory of Law-Grundnorm'. The verdicts of legitimizing the armed coups and military governments through constitutional cases have never been proved beneficial for the state and its citizens. As in all the armed coup, citizens have no fundamental rights to ensure the legitimate core rights of all citizens through courts because the courts jurisdictions were already ousted by the PCO's. By allowing General Zia-ul-Haq and General Pervez Musharraf to amend the Constitution of Pakistan, the role of judiciary became more controversial except the basic structure of the constitutions. The judicial decisions on these famous constitutional cases are interesting to study the constitutional development and the role of judiciary in protecting its independence in Pakistan.

The state apex judiciary is always the last hope of its citizen and a powerful toll to finally adjudicate a matter, not only according to the state law but shall ensure justice at any cost. It is not a privilege but a duty and obligation of the judiciary to ensure the guaranteed fundamental rights, as enshrined in chapter 2 of the Pakistan constitution 1973 for its citizen (Naazer et al., 2017). In modern society, with the younger generation equipped with more knowledge and intellectual power to differentiate, inconsistency in applying the law as interpreted by the superior judiciary in disparate manner, eventually lead to disrespect for the courts and ultimately caused, chaos and shook the state foundations. Certain unpopular politicians used to invite Martial law when they found no way through electoral practices. Similarly, a mind set in the military establishment remained alert for such adventurism and opportunities to take over the future of state (Niazi, 1986). Luckily and unluckily the state and also the act of the military rules one way or the other way and provisional constitutional orders are issued immediately besides the order of a fresh oath taking for the Honorable justices of the supreme judiciary. To be the judges of Pakistan's High court and supreme court. The fresh oaths were of allegiance of the military rulers.

Actually, the courts provide a forum for constitutional dialogue under the patronage of Pakistan judiciary who has taken a fresh oath of allegiance to the military rulers and thus they adjudicate the constitutional petitions before them. The selected relevant cases on the subject i.e., Maulvi Tamizuddin Case, Dosso case, Yusaf Patel's Case, Asma Jilani's Case, Begum Nusrat Bhutto's Case, Syed Zafar Ali Shah case are of special concern in this study. This study is also going to 
The role of superior judiciary in protecting its independence: A case study of judicial ...

critically analyze and review these petitions/judgments points of view in detail to see the independence of judiciary at that very moment. These cases are quoted as base for providing the way out or way in for imposing martial law in the country time to time and again. The court verdicts on these petitions have adversely affected the spirit of the constitution of Pakistan and also the flourishing of political institutions in the country. In the long run the consistency in any process of development was affected due to ad-hoc-ism in the policies of all institutions.

The Supreme Court got embroiled in politics when on October 24, 1954, Governor-General dissolved the Constituent Assembly, declared a state of emergency and dismissed the Prime Minister along with his Council of Ministers. The President of the Constituent Assembly, Maulvi Tamizuzddin Khan, instituted a writ petition in the Sindh High Court which was accepted. The petition was instituted under section 223-A which was introduced by amending Government of Indian Act 1935 (as adopted to Pakistan as an interim constitution) which was appealed by the Federation of Pakistan. The Federal Court headed by the Chief Justice Muhammad Munir took a strange view in the instant petition that article $223 \mathrm{~A}$ which had been incorporated by amending Government of Indian Act 1935 was not a valid law on the ground that the assent of the Governor General was not granted to it (a piece of legislation). Hence it was not a valid legislation to be considered as a valid part of the Constitution. While since 1947 to 1954 different acts were passed by the parliament, which were not presented to the Governor General for his ascent. The action of rejecting the petition of Maulvi Tamizuddin Khan created a constitutional chaos and coup in the country (PLD 1955 FC 240). The question of Governor General's dissolution of the constituent assembly was not decided on merit.

In fact, in a state of emergency, the supreme judiciary of the state has to play a vital role and shall prove its independence protect the system, citizen civil, legal, political rights while adjudicating the imposition of martial laws. At such crucial time it becomes a great challenge for the judges of the superior court because the judiciary in her the power examine coup de ate and to declare the transition whether permanent or temporary legal or illegal. During the examination of such like cases different questions are placed before the superior court to be responded in the judgment of the validation or invalidate of the imposition of martial laws. The circumstances which eminently needed military adventurism, the cause and effect of their intervention failure of the existence system and there was no practical amicable legal solution to the internal and external disturbance in the state, history of the state relating to such transaction if any, that is legal and factual precedent timing of pronouncement of judgment particularly when the usurper was in power or otherwise, is also important, is such like cases which would judge the real independence of supremacy of state judicial system and the guardian of the state constitution in true spirit.

Pakistan is a state having a codified constitution and in such state the judiciary has the power to examine the acts of the executive or any other public body on the touch stone of the doctrine of judicial review that whether the act contemplated was constitutional or otherwise. The imposition of martial law of armed coups in Pakistan were challenged either directly or indirectly before the supreme court of Pakistan but the final verdicts were delivered by the supreme court of Pakistan which were a future direction of the innocent people of Pakistan, and they were subject to the musical chair game of the institution. The case of Dosso, decided earlier had justified the imposition of martial law by General Ayub Khan but the same supreme court for the first time invalidated, constitutional the armed coup of General Yahya Khan, by declaring him as usurper in Asma Jilani case, when he was not in power. According to a 
renowned politician and a senior parliamentarian Aftab Ahmad Khan Sherpao, "The decision in the Asma Jilani case by the supreme court was a very good" (Aftab Sherpao, 2020).

A similar view was articulated by Afrasiyab Khan Khattak an intellectual, political scholar and politician on the matter, the courts attempted in this case to cover up their previous mistakes (Afrasiyab Khan Khattak, 2020). While on the other hand a foreign qualified advocate of Supreme Court says that "It was neither remarkable nor a good decision but rather damaged the judiciary and democratic setup" (Jawad Ahsan, 2020). Another legal fraternity is of the view that as it was decided after the rule of General Yahya Khan and doctrine of necessity was buried but the principal as evolved that under the cannons laws remain silent" (Tariq Hotti, 2020). The difference of opinion on late pronouncement of this judgment whether deliberate or otherwise, this is a dilemma that the court invalidated military intervention, and an extra constitutional act only when the dictator was no more in power or about to leave, which shows how liable judiciary, how important impartial and independent judiciary should be. But justice delay is a justice denied. Because if a judicious decision is delivered at an appropriate time, then the aggrieved parties would get a sigh of relief. If General Yahya was declared as usurper before the civil disobedience in East Pakistan and military operation, hopefully the situation would have been different, and India would never had got the opportunity to interfered with Pakistan's internal affairs.

Similarly, promulgation of emergency grounds of allegations against the civil government were almost identical (Hamid Khan, 2020). All the time it was a power hunting games. And according to Sardar Latif Khosa the then attorney general of Pakistan, General Zia martial law was focused to depose Zulfiqar Ali Bhutto government through some integrated forces in the name of Islam (Bakht Munir, 2020). The General Zia Martial law was directly challenged under article 184(3) of the 1973 constitution of Pakistan before the Supreme Court of Pakistan at the dint of fundamental rights, questions of public importance and reliance was placed on Asma Jilani's case ratio decidendi besides other arguments which were placed before the honorable court (Tariq Hoti, 2020). The supreme court of Pakistan not only overruled/distinguished the Asma Jilani case by exhumation of the doctrine of necessity. It has not only legalized Dosso case and Islamization but also authorized the chief of army staff to amend the constitution. While the power of amendment of the constitution is beyond the jurisdiction of the Supreme Court. Which depicts that the establishment had fully controlled the Superior Judiciary, and as they had already taken oath of allegiance of the military ruler.

In this context the parliamentarians' legal fraternity and legal scholars having a unanimous view, that the honorable judges of higher judiciary surrendered themselves to the military dictators and judiciary became a laughing-stock itself. No one can say that this judgment (Nusrat Bhutto vs Chief of Army Staff) was a legal, judicial or judicious decision (Latif Khosa, 2020). But it opened a flood gate for future military dictatorships (Hamid Khan, 2020). And the application of Kelsen's theory of validation of imposition of emergency was not a prudent decision, as admitted by the Supreme Court in its judgments of Sindh High Court Bar Association vs Federation of Pakistan I would like to refer to Aftab Sherpao comments, "When the Honorable judges had taken oath of allegiance of the chief of Martial law administrator under PCO, and it was a pre-decided case in favor of the martial law administrator" (Sindh High Court bar association vs federation of Pakistan, 2009). Consequently, upon legalization of General Zia armed coup by the supreme court of Pakistan, Military Generals were encouraged to imposed martial laws in future, reference is made to the General Pervez 
The role of superior judiciary in protecting its independence: A case study of judicial ...

Musharraf armed coup in October 1999 by which he dismissed an elected government and imposed martial law/emergency once again after almost a decade (Aftab Sherpao, 2020).

The supreme court was not secure from the acts of military and establishment they were fully controlled and thus were known to legalize the act of Army chief, as the Supreme judiciary of Pakistan were remained influential in deciding constitutional matters, notwithstanding that the courts were constituted under the PCO by taking a fresh oath of allegiance of the military ruler and thus the judges of the superior courts were subordinate to the executive. In martial law we have no Supreme Court at all (Atta Ullah, 2020). The case of General Musharraf martial law/emergency imposition was validated also as judiciary and military establishment have nexus and have no good role. The judiciary provides a legal stamp to the army generals. A political system cannot grow in such like circumstances as hand and gloves (Latif Khosa, 2020). On the other hand, General Musharraf was declared a usurper as per case titled Sindh High court Bar Association vs Federation of Pakistan. While in context of the General Musharraf martial Law imposition validation a renowned lawyer and writer stated, "power speaks itself and it was a joke with the nation" (Hamid Khan, 2020). Aftab Sherpao was of the view that in Martial laws in Pakistan judiciary was always weak and was saving her face thus they were good hand maid of the state under the PCOs (Aftab Sherpao, 2020).

In addition to the above, the Pakistan constitutional system and mechanism is very much effective, wide enough, the forefather and framer of the constitution have left no stone unturned, to provide remedy to each and every obvious eventuality but a lacuna is inherent in our nation that our expectations are high, and we wish abrupt changes/results. While in a democratic system, to eat the food of democracy, a nation should pass through a process of evolution. Democracy is not the name of a revolution. Therefore, we shall not opt for short cuts and there is a no royal rode in a democratic system to eat its fruits before the proper time. The adaptation of shortcuts not only breakdown the democratic journey but also deteriorate the existing democratic culture. In this connection the role played by the state institutions and political parties is discouraging. Particularly judiciary is the custodian of legal, political and fundamental rights, as well as guardian of its self-independence under the basic structure of the Pakistan constitution. It is astonishing that "our courts remained very influential in deciding constitutional matters. How come a court constituted under PCO and oath order could declare the PCO and oath order invalid? Fragile democratic system and other challenges faced by Pakistan since its establishment where in military remained as an unavoidable stakeholder.

In absence of security to the honorable judges, their immediate family members and properties, we should not expect impartial and unbiased decisions" (Ali Nawaz Khan, 2020). The Honorable Judges of the Supreme Court were subjugated by power absolutely (Hamid Khan, 2020). And the Supreme Court of Pakistan did not play a role of independent judiciary but of a loyal servant (Aftab Sherpao, 2020). Literary criticism on the Apex court points out prejudice when it validated martial law under pressure, favoring those in power. In fact, it was the most significant factor behind the lawyers' movement to eradicate favoritism and related elements for a free and impartial judiciary (Mehboob Hussain, 2020). Apart from this all these complicated and compromise judgments worsened the legal and political system of Pakistan and thus there was no stability flourished. In this democratic transition the political system of Pakistan oscillated between military and civilian government. On validation of military interventions, democratic system was adversely affected and reversed by these judgments. It may be said that two step forward one step backward (Ali Nawaz, 2020). 
The legal and political system of Pakistan has been deteriorated to a point of almost no retirement (Qazi Muhammad Anwar, 2020). Thus, as a result of these judgments delivered by the Apex court did not improve the political system of Pakistan. Rather it derailed the political process, curtail the fundamental rights of the people of Pakistan and independence of judiciary and electoral process suffered too. The judgments tied the hands of judiciary and served martial laws which the judiciary realized itself when General Musharaf acted against the superior judiciary and then they cried for judicial independence (Mehboob Hussain, 2020). So, these political compromised judgments to improve the misery of people of Pakistan and judiciary itself (Aftab Sherpao, 2020).

In fact, Pakistan forefathers had desired and also had to hesitate in purpose of state incapacity to rise above colonial inheritance inability to democratic, articulation and constitutional principles which were characterized by the independence movement (Newberg, 2002, p. 10). It is clearly elaborated in the objective resolution of Pakistan 1949, that judiciary independence shall be protected in the state of Pakistan to secure and safeguard the core basic rights of its citizen (Zafar, 1991). It is also pertinent to mention that judicial activism be maintained as per Islamic principles, ideology and morality by the courts while interpreting and adjudicating an issue (Benazir Bhutto vs Federation of Pakistan, 1998). The jurisdiction of the Court as to give effect to the Islamic principles of Quran and Sunnah is a duty (Bank of Oman vs East Treading company, 1987). The Courts have an inherent power of interpretation according to the law and these powers are not constitutionalized as in the constitution of USA (Fouji Foundation vs Shamim ur Rehman, 1983).

The judges of superior court shall be conscious of their responsibility while adjudicating and ceased to be biased to any party except to do justice and shall grant relief to the citizen of Pakistan. And the court shall keep alive, state law even in martial law and shall grant remedy to the citizen of Pakistan against any violation by the way of judicial review power in the supreme Court (Begum Nusrat Bhutto vs Chief of Army Staff, 1977). The Federal Court of Pakistan judgment was written by Chief Justice Muhammad Munir. His biased decision has been heavily criticized by various scholars, for instance, according to Qudratullah Shahab that Justice Munir was communicated the Governor General message to justify his action which was in fact perceptibly mala fide (Shahab, 1992, p. 664). Justice Munir apologized and remained defensive of his judgment in the Tamizuddin Khan Case throughout his life. At the time of his retirement Justice Munir stated at bar that his court had issued and enforceable writ against a de-facto government on October 9/10, 1955. That had been broad revolution in existence by the Governor General while there was no revolution on February 1955 (Hussain, 1973, p. 61). These are the lame excuses of a guilty person Justice Munir's justification could not convince a legal or reasonable mind. But his reasoning revolves around his own presumption and apprehension of the consequences (Khan, 2002).

As the first constituent assembly was dissolved and its president Tamizuddin Khan approached the Sindh High Court for appropriate writ, which was granted against the government of Pakistan. The state of Pakistan appealed before the federal Court of Pakistan. The case came before the Federal Court Tamizuddin Khan case for Pakistan judiciary was a test case which they lost, and the establishment won it through not fully. This judgment created a great constitution vacuumed in the country which had neither constitution nor notational assembly (Zafar, 2019). According to Justice Munir, "a constitutional law is not the cause but a consequence of personal and political freedom" (Newberg, 2002, p. 9). 
The role of superior judiciary in protecting its independence: A case study of judicial ...

In Dosso Case Justice Cornelius tried to protect the rights which the judiciary could not protect in that newly create scenario (Newberg, 2002, p. 548). This situation has been termed by Newberg as "acquiesce vs non-cooperation" (Newberg, 2002, p. 77). Due to the supreme judiciary innovated jurisprudence of crises to had justice in conflict and inconsistencies. In fact, it is a conflict of hope of democracy and reality (Newberg, 2002, p. 549). As per Chief Justice Hamood ur Rehman to presume Kelsen's theory is universally recognized was wrong (Asma Jilani vs Federation of Pakistan, 1972). Likewise, the cases of Nusrat Bhutto and Syed Zafar Ali Shah were almost had similarity in contents and their ratio decidendi are identical in both cases the Supreme Court of Pakistan authorized the chief, of Army Staff to amend the constitution to the need of exigency but not to change the basic structure of the constitution (Begum Nusrat Bhutto vs Chief of Army Staff, 1977). It is worth to mention the justice Munir himself had embraced in Lahore High Court "he declared a comparable position of a military ruler declaring military necessity of a civil ruler declaring evil necessity. Letter on the two were mixed up as military coups detate were justified on its basis of evil necessity (Muhammad Umar Khan vs the Crown, 1953).

In Pakistan the superior judiciary had to mediate in the conflict among the institutions of government more frequently about the distribution of powers, but the courts were consistently instrument of the government's agency has been treated as its other institution. The superior courts have tried to bridge the gulf of institutional incompatibilities. The superior judiciary was of evidence in society and politics apart from its legal and constitutional status, through their judgment. They influenced profoundly state institution to accommodate each other and resolve their differences, through literately judging the state constitutional issue, of ruling, directly affecting the national sovereignty. The validated coups which were imposed by the various chief of Army staff of path at different timing in its history. The superior judiciary attempted to restructure the transition, between military Pakistan Army Governance of Civil Government also the court of Pakistan had become insurgencies in the transition. Actually, the superior judiciary validated equitably almost armed coups rather than privilege. The courts were used by those who were in powers and those who were seeking power to address their grievances against the state and the citizens were ignored. It can be termed as an institutional manipulating by the ruler on hypothesis and presumption (Newberg, 2002, p. 12). The honorable judges of superior courts were much obliged with limitation on their jurisdiction and extension of the executive power rule which was inconsistent and incompatible with the judicial foundation of Pakistan (Newberg, 2002, p. 12).

As per an American judge, "Sooner or later all political questions finally land up before the superior Courts for resolution. Many times, the level of dialogue in the courts developed color of tone of a grand seminar, where amicus curiae or collectively interested institution like bar association are invited and allowed to express views. Judges become active participants is widened for resorting the concept such as public-spirited litigation. Finally, the superior Courts have not only provided a forum for dialogue but on occasion helped a national consensus of or agreement of between the intuitions or even a catharsis. The view of the matter that a judge made law means enacting into the law a part of the system a social and political Philosophy" concluding when the Court as a result of the fully debated dialogue assimilate the social environment of the country give effect to its contemporary values by enacting them into the system of law. The act not only as the interpreter of law on behalf of parliament but also as a national institution on behalf of the society. They cannot be equated to a group of elites taking decision in isolation from society and acting in anti-majoritarian strain. Contrary to this 
Supreme Court in a national institution and must act accordingly Supreme Court a national institution forum for Dialogue (Zafar, 1973).

\section{Conclusion}

As a result of the study, survey conducted, and the imminent lawyers and political figures of Pakistan, the post of a judge is of high caliber and integrity. It is the third pillar of a democratic system all over the world but if the judiciary itself diminish their supreme power of adjudication according to the state law and specifically as an Islamic state it is not only a ridiculous but a state of astonishing that they cannot protect the legitimate and guaranteed rights of the constitutions as well as of Islam. Dispensation of justice is always be adhered even if the sky falls. The honorable judges shall not consider themselves only a servant of the state but to adjudicate on the principle of rule of law. Service is that tool of executive and establishment by the dint of which they ruled the state as per law of the rule not according to the rule of law. Although various courageous honorable judges of the apex judiciary have attempted to ensure justice, rule of law but unfortunately and honestly, we are not on a right track to give due right to the due person as enshrined in the Islamic Republic of Pakistan Constitution 1973, Quran and Sunnah. One can rule by the dint of force but not through injustice. Hence, the Judgment delivered by the Honorable Judiciary in armed coup d'état cases, could not be termed judicious except in case of Asma's Jilani case but are of a public servants' judgment to please their lords and were endorsed on proclamations order as those were brainchild of a very high caliber judicial institution of Pakistan. The decisions were neither appropriate nor appreciated, nationally as internationally but are black moles on the history of Pakistan.

\section{References}

Asma Gillani Vs Federation of Pakistan (1972), page 139, PLD Supreme Court.

Bank of Oman vs East Treading Company (1987), page 404, Karachi.

Begum Nusrat Bhutto Vs Chief of Army Staff (1977), page 657, PLD Supreme Court.

Benazir Bhutto vs Federation of Pakistan (1998), page 416, PLD Supreme Court.

Choudhury. G. W. (1959). Constitutional development in Pakistan. Cambridge University.

Chaudhri, N. H. (1973). Chief Justice Muhammad Munir: His Life, Writings, and Judgements. Research Society of Pakistan.

Dicey, A. V. (1885 [1959]). Introduction to the Study of the Law of the Constitution (Tenth edition). London New York, Macmillan. Lahore Publication.

Fouji Foundation vs Shamim ur Rehman (1983), page 457, PLD Supreme Court.

Hamid Sarfaraz vs Federation of Pakistan (1979), page, 991, PLD Supreme Court.

Hussain, C. H. (1973). "Chief Justice Munir” his life writing and judgments. Research Society, Punjab University, Lahore.

Ishtiaq. A (2013). Pakistan is a Garrison state. Oxford University.

Khan, H. (2005). Constitutional and political history of Pakistan. Oxford University.

Mahmood, S. (1990). Constitutional foundations of Pakistan (2 ${ }^{\text {nd }}$ Ed.). Jang Publishers. https://catalogue.nla.gov.au/Record/2248236

Muhammad Umar Khan vs the Crown, 1953.

McGrath, A. (1996). The destruction of Pakistan's democracy. Oxford University. https://catalogue.nla.gov.au/Record/2995237 
Naazer, M. A., Mahmood, A., Ashfaq, S. (2017). An Analysis of Political Rights Situation during Musharraf Regime (1999-2004). Liberal Arts and Social Sciences International Journal (LASSIJ), 20-31. https://doi.org/10.47264/idea.lassij/1.1.3

Newberg, P. R. (2002). Judging the state: Courts and constitutional politics in Pakistan. Cambridge University. http://pgil.pk/wp-content/uploads/2015/11/CambridgeSouth-Asian-Studies-Paula-R.-Newberg-Judging-the-State -Courts-andConstitutional-Politics-in-Pakistan-Cambridge-University-Press-1995.pdf

Niazi, K. (1986). Aour line khat gaye (pp. 191-198). Jang Publisher.

Sahab, Q. U. (1992). Shahabnama. Sang-e-meel Publisher.

Sindh High Court bar association vs federation of Pakistan (2009), page 789, PLD Supreme Court.

Zafar, S. M. (2019). History of Pakistan Reinterpreted. Manzoor Law Book House.

Zafar, E. (1991). The Constitution of Islamic Republic of Pakistan, 1973. Irfan Law Book House.

\section{List of Interviews}

Afrasiyab Khan Khattak (2020, September). Scholar writer and Senior Parliamentarian. Aftab Sherpao (2020, November 3). Ex. Chief Minister and Senior Parliamentarian.

Ali Nawaz Khan (2020, November 4). Assistant Professor of Law, Punjab Law College, University of Punjab, Lahore.

Atta Ullah (2020, September 22). Assistant Professor Islamic University Islamabad.

Bakht Munir (2020, November 27). Assistant Professor of law, Punjab Law College, University of Punjab, Lahore.

Jawad Ahsan (2020, October 20). Advocate Supreme Court of Pakistan.

Hamid Khan (2020, November 3). Writer and Senior Advocate Supreme Court of Pakistan.

Tariq Hoti (2020, June 23). Advocate Supreme Court of Pakistan.

Latif Khosa (2020, November 5). Ex. Attorney Journal and Senior Advocate Supreme Court of Pakistan.

Mehboob Hussain (2020, November 4). Head of Department, Department of History, University of Punjab, Lahore.

Qazi Muhamamd Anwar (2020, June 17). Ex. Advocate General and Parliamentarian. 